\title{
EDITORIAL
}

\section{Impactos del cambio climático global sobre la estrategia de producción fuera de estación en la Región de Arica y Parinacota}

\author{
Impacts of global climate change on the off-season production strategy \\ in the Arica and Parinacota Region, Chile
}

Luis Tapia Iturrieta

M.Sc. Economía Agraria Universidad de Tarapacá Arica-Chile ltapia@uta.cl

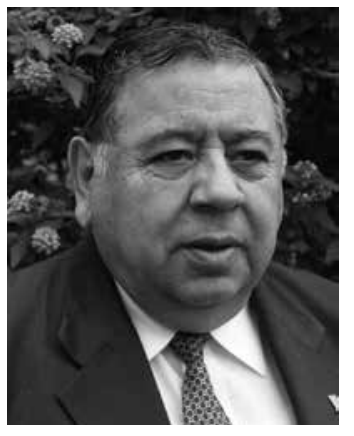

M.Sc. Agricultural economy University of Tarapacá Arica-Chile ltapia@uta.cl
Por tradición los agricultores de los valles de la región de Arica y Parinacota han adoptado como costumbre la estrategia de producción fuera de estación para sus primores con el fin de aprovechar las condiciones de inviernos benignos. Esta realidad climática proyectada en el tiempo ha permitido transformar al valle de Azapa como el principal productor de tomates del país en el periodo invernal, que representa el $50 \%$ de la producción nacional al considerar la temporada anual.

Los impactos del cambio climático a nivel mundial que afectan al hemisferio sur se manifiestan en alteraciones en los inicios y en el término de los periodos de la estación de invierno y cambios en los rangos de las variables climáticas que se traducen en efectos de retraso en el inicio de las estaciones o en algunos años con marcado adelanto de los periodos críticos de temperaturas que requieren los cultivos hortícolas.

Esta situación obliga a considerar que la estrategia de producción fuera de estación se está viendo afectada por lo errático de la situación agroclimatológica, que altera los resultados financieros de los cultivos, que están siendo producidos en los valles de la región de Arica y Parinacota. La llamada "ventana" de favorables condiciones climáticas que se espera normalmente se genere en el norte
Farmers in the valleys of the Arica and Parinacota Region of Chile have traditionally adopted the strategy of off-season production in order to take advantage of the benign winter. This climatic reality has transformed the Azapa Valley into the main producer of tomatoes in the country in winter; this represents $50 \%$ of the national annual production.

The impacts of world climate change are manifested in the Southern Hemisphere as alterations in the beginning and end of the winter season and changes in the ranges of climatic variables; these include delays in the beginning of the seasons, and in some years a notable advance in the critical temperature periods that cultivated vegetables require. This situation requires considering that the strategy of off-season production is being affected by the erratic agricultural-climatic situation, altering the financial results of the crops which are being produced in the Arica and Parinacota Region. The so-called window of favorable climatic conditions which was usually generated in northern Chile is being altered. The decisions to plant crops is taken beforehand by producers to initiate their production; thus farmers, especially those who 
de Chile se ve alterada y las decisiones de iniciar los cultivos ya fue tomada por los productores con anticipación para iniciar su plan de producción. Por lo tanto, los agricultores, principalmente tomateros, se encuentran en un área de incertidumbre que afecta a los resultados económicos en cada cultivo.

¿Qué se puede esperar de la evolución de las condiciones climáticas?

Por un lado, la normalidad de las condiciones agroclimatológicas entra en una fase de carácter errático que compromete a los resultados económicos que los cultivos generan en los valles costeros del norte de Chile. La estrategia de producción fuera de estación comienza a tener inconsistencias que son generadas por factores climatológicos globales.

Esta situación obliga a incorporar una nueva condición de incertidumbre en el plan gestor de los productores de primores del norte de Chile, la que está asociada a una condición errática ligada a factores mundiales que afectan al cambio climático global planetario y en particular a las condiciones que se presentan en el hemisferio sur.

La respuesta de los competidores de la zona centro sur de Chile ha sido reducir los riesgos con una mayor artificialización en los cultivos de tomate que implica mayores inversiones, para tener éxito con la producción y alcanzar el periodo de mejores precios en tomate durante la temporada invernal.

Los consumidores, por su parte, ya tienen internalizado que la estacionalidad se ha reducido y están dispuestos a consumir tomates todo el año, de ahí que estos problemas se resuelven por la vía de los precios en el mercado y finalmente es el consumidor quien termina pagando estos impactos.

En resumen, el cambio climático que afecta al planeta y en particular al hemisferio sur está generando situaciones de inestabilidad para poder mantener la estrategia de producción fuera de estación para los primores producidos en el norte de Chile. La respuesta de los agricultores se implementa mejorando la calidad y llegar con precios competitivos al mercado de la zona central y, además de trabajar, en tratar de incorporar a la exportación de tomates hacia los países del cono sur, como complemento, en la colocación de la producción de tomates que se generan en el norte de Chile. plant tomatoes, are faced with uncertainties that effect the economic results of each crop.

How may we expect the evolution of climatic conditions to occur?

The climatic conditions for agriculture are becoming erratic, with important economic consequences for the crops grown in the coastal valleys of northern Chile. The strategy of off-season production is beginning to have inconsistencies generated by global climatic factors. This situation obliges vegetable farmers in northern Chile to incorporate a new condition of uncertainty, which is associated with an erratic condition linked to global factors that affect the global climate change and in particular the conditions that occur in the Southern Hemisphere.

The response of the competitors in the southcentral zone of Chile has been to reduce risks by adopting artificial measures in tomato cultivation that require more investment to assure success in production and include the period of higher tomato prices during winter. Consumers have now accepted that the crop is no longer seasonal and are willing to buy tomatoes all year long; the difficulties are solved by the increase in market prices and it is the consumer who finally pays the price of these impacts.

Summarizing, the climatic change that affects the entire planet and particularly the Southern Hemisphere is generating situations of instability to maintain the strategy of off-season production for vegetables produced in northern Chile; the response of farmers is implemented by improving quality and achieving competitive prices in the markets of the central zone. They are also attempting to incorporate the exportation of tomatoes to other countries of the Southern Cone as a new market for the tomato production generated in northern Chile. 